\title{
COMMENTS
}

\section{RELIGIOUS LIBERTY AND THE RELIGIOUS GARB}

\author{
VIRGII C. BLUM, S.J.*
}

On June 8, 1953, the Supreme Court of Missouri handed down an opinion in Berghorn v. Reorganized School District ${ }^{1}$ that has far-reaching implications for religious liberty. This case involved the right of school teachers wearing the religious garb to teach in public schools. The doctrine enunciated by the court in denying this right is decidedly different from that stated in other decisions barring religious women from public school classrooms. In the Berghorn case, the Missouri court barred these women from the public schools solely because of their religious beliefs and not because of any religious influence that they might have on the children by reason of their attire and practice of Christian virtues. The doctrine proclaimed by the Missouri court, more so than that of any other judicial decision in a religious garb case, sharply raises the important question of religious liberty and freedom of conscience.

In the opinion, the Supreme Court of Missouri declared that "because of the character of their obligations ... nuns are disqualified from teaching in any public school in the State of Missouri."2 This doctrine rests their expulsion squarely on the nature of their religious belief.

The right of teachers to wear the religious dress in the classrooms of public schools was challenged for the first time before a state supreme court in 1894 in Hysong v. School District of Gallitzin Borough. ${ }^{3}$ The Supreme Court of Pennsylvania rejected the contention that the wearing of the religious dress amounted to sectarian teaching. ${ }^{4}$ But the following year, the state legislature effectively annulled the decision by prohibiting the wearing of religious dress in the public schools, ${ }^{5}$ and the supreme court upheld the legislation. ${ }^{6}$

In later decisions, the highest courts in New York, ${ }^{7}$ Iowa, ${ }^{8}$ and New Mex-

* Assistant Professor of Political Science, Creighton University.

1 - Mo. —, 260 S.W. 2d 573 (1953).

2 Tbid., at —, 579 .

${ }^{3} 164$ Pa. 629, 30 Atl. 482 (1894).

'Ibid., at 654-56, 482-84.

${ }^{5}$ Pa. P.L. (1895) 395.

- Commonwealth v. Herr, 229 Pa. 132, 78 Atl. 68 (1910).

' O'Connor v. Hendrick, 184 N.Y. 421, 77 N.E. 612 (1906).

${ }^{8}$ Knowiton v. Baumhover, 182 Ia. 691, 166 N.W. 202 (1918). 
$\mathrm{ico}^{9}$ denied the right of teachers in religious dress to teach in the public schools on grounds that the school systems should remain free of sectarian influence. However, in North Dakota ${ }^{10}$ and Indiana, ${ }^{11}$ the highest state courts have followed the Hysong decision and sustained the right against the additional contention that paying teachers who wear the religious dress in the public schools was a mere subterfuge by which donations were unlawfully made to a religious order.

This comment will discuss the judicial reasoning in these decisions under three headings: (1) Religious Liberty and the Religious Vows, (2) Religious Liberty and the Religious Dress, and (3) Is a Virtuous Life Cause for Dismissal?

\section{Reitgious Liberty aNd the Religious Vows}

Man's relations to God are sacred. The state may not intrude its secular arm into the domain of personal conscience. Concerning a man's "relations to his Maker and the obligations he may think they impose," declared the Supreme Court of the United States in Davis v. Beason, ${ }^{12}$ "and the manner in which an expression shall be made by him of his belief on those subjects, no interference can be permitted." This fundamental principle of religious liberty has been frequently reiterated by the Supreme Court.

The First Amendment has a dual aspect. It not only "forestalls compulsion by law of the acceptance of any creed or the practice of any form of worship," but also "safeguards the free exercise of the chosen form of religion."13 As the Court declared in Cantwell v. Connecticut, "The Amendment embraces two concepts-freedom to believe and freedom to act. The first is absolute but, in the nature of things, the second cannot be."14 Because of the essentiality of freedom of thought in our democratic society, under our Constitution "man's relation to his God was made no concern of the state."15 The Court in that case held that the First Amendment applied to the states as well as to the federal government.

In 1894, the Supreme Court of Pennsylvania found no great difficulty in adhering to fundamental principles of religious liberty in Hysong v. School District of Gallitzin Borough. "The particular belief of the sisters," declared the court, "does not disqualify them. Our constitution negatives any assertion of incapacity or ineligibility to office because of religious belief."16 Exclusion from office or other position of public trust as a penalty for one's religious be-

${ }^{\circ}$ Zellers v. Huff, 55 N.M. 501, 236 P. 2d 949 (1951).

${ }^{10}$ Gerhardt v. Heid, 66 N.D. 444, 267 N.W. 127 (1936).

${ }^{11}$ Johnson v. Boyd, 217 Ind. 348, 28 N.E. 2d 256 (1940).

12133 U.S. 333, 342 (1890).

${ }^{13}$ Cantwell v. Connecticut, 310 U.S. 296, 303 (1940).

"Ibid.

${ }^{15}$ U.S. v. Ballard, 322 U.S. 78, 87 (1944).

${ }^{10} 164 \mathrm{~Pa} .629,665,30$ Atl. 482, 483 (1894). 
lief may not be tolerated. "There can be, in a democracy," urged the court, "no higher penalty imposed upon one holding to a particular religious belief than perpetual exclusion from public station because of it. . . . We cannot ... establish a religious test as a qualification for office."17

The constitution of New York declares that "the free exercise and enjoyment of religious profession and worship, without discrimination or preference, shall forever be allowed in this State to all mankind. . . ."18 This guarantee of "religious profession and worship" presupposes personal freedom of conscience in determining one's personal relationship to God including the vows of poverty, chastity, and obedience.

Notwithstanding the state constitutional guarantee, a New York court declared, in O'Connor v. Hendrick, 18 that "these sisters should never be permitted to teach in our public schools. From the very nature of their vows and lives, they should not be permitted to have the care and instruction of young persons without the free consent of their parents." 20 Enlarging on what it meant by the "nature of their . . . lives," the court declared that these women "were to be always poor, have absolutely nothing, surrender all they had or should receive to the order. ... They were never to marry. ... They were to obey the order and the church implicitly in all things."21 These things are entailed in living a life of poverty, chastity, and obedience. However, this status in no way renders the teacher less able or less ready to fulfill the obligations of the public school teacher. ${ }^{22}$ To discriminate against a person who has entered into this more intimate relationship to God is a violation of freedom of thought and freedom of religion. It is submitted that the New York court violated these liberties when it held that "these sisters should never be permitted to teach in our public schools."23 These teachers were forever barred from the teaching profession because of personal dedicatory promises made to God. Though on appeal the Court of Appeals of New York unanimously affirmed the decision of the supreme court, it did not acquiesce in the view that "these sisters should never be permitted to teach in ... public schools." 24

${ }^{27}$ Tbid.

${ }^{28}$ N.Y. Const. Art. I, $\$ 3$.

${ }^{10} 109$ App. Div. 361, 96 N.Y. Supp. 161 (4th Dep't, 1905).

${ }^{20}$ Ibid., at 372,169 . It is respectfully submitted that one may well question the competence of the court to speak authoritatively of "the very nature of [the] vows" when it is noted that the court is ignorant as to what vows are taken by religious women. The court stated that these women "were governed by rules providing vows of purity, chastity, and obedience."

II Tbid.

${ }^{22}$ It need hardly be pointed out that such teachers are, in academic affairs, as much subject to the control and jurisdiction of public school officials as are lay teachers.

${ }^{23}$ O'Connor v. Hendrick, 109 App. Div. 361, 372, 96 N.Y. Supp. 161, 169 (4th Dep't, 1905).

${ }^{2}$ O'Connor v. Hendrick, 184 N.Y. 421, 430, 77 N.E. 612, 615 (1906). 
Freedom to believe was sharply challenged in the Berghorn case in Missouri. The question before the court was whether teachers could be barred from the public schools because of spiritual obligations to God that they had assumed by pronouncing religious vows. This court held that these teachers could be barred; it is apparent that they were discriminated against solely because of their religious beliefs.

The lower court had declared that "regardless of the garb which said nuns may wear [they] may not lawfully be employed as teachers in any free public school."25 On analysis, this means that these women may not be employed as teachers because they are nuns. But they are nuns because of a special spiritual relationship to God, based on their three vows. Hence, it must be concluded that they are barred from employment as teachers because of their relations and allegiance to God.

Religious-minded Americans have grown accustomed to making contributions to religious organizations for reasons of spiritual motivation and conviction. This practice is considered so laudable and so beneficial to the general welfare that it is public policy to exempt such contributions from income tax assessments. Such governmental encouragement is the antithesis of governmental efforts to prohibit contributions or to discriminate against those who turn over a portion of their earnings to a religious purpose. The state encourages a practice which it could not forbid without serious violations of religious liberty.

When the Supreme Court of Pennsylvania was asked in the Hysong case to disqualify women from public school teaching because, among other things, they contributed some of their earnings to a religious purpose, the court declared, "[I]t is none of our business, nor that of these appellants, to inquire into this matter."26 This is a personal matter, involving one's relations to his Maker. There would be as much justification, said the court, to inquire of a lawyer, before admitting him to the bar, what he intended to do with his surplus fees, and make his answer a test of admission. ${ }^{27}$

On the same issue, the Supreme Court of North Dakota, in Gerhardt v. Heid, $^{28}$ declared that the fact that these teachers contributed a material portion of their earnings to a religious order "is not violative of the Constitution." Speaking less than twenty years before the Berghorn decision, the court said that the denial of the right to make such contributions "would in itself constitute a denial of that right of religious liberty which the Constitution guarantees."28

${ }^{25}$ Berghorn v. Reorganized School District, Circuit Court of Franklin County, Mo., April 21, 1952.

${ }^{23}$ Hysong v. School District of Gallitzin Borough, 164 Pa. 629, 656, 30 Atl. 482, 484 (1894).

${ }^{27}$ Tbid., at 657,484 .

${ }^{28} 66$ N.D. 444, 267 N.W. 127 (1936). $\quad$ Thid., at 459, 135. 
Nevertheless, the Missouri court in the Berghorn case held that a promise to God to turn over one's earnings to a religious purpose disqualifies a person from a teaching position in the schools of the state. Asserted trial judge Crouse: "The court declares that the nuns ... are by virtue of their vows of poverty and of obedience ... disqualified from employment as teachers in the free public schools of Missouri. . . ."30 Here the court is entering the sacred domain of conscience and of religious belief. It is interfering with the right of the individual to turn over the proceeds of his labors to a religious cause.

\section{ReLigtous Ltberty AND the RELigious DResS}

The wearing of the religious dress in the public school classroom may best be treated in two parts: (1) The Liberty of the Individual To Choose His Attire, and (2) The Religious Dress: An Insignia of Belief, or a Didactic Device.

\section{The Liberty of the Individual To Choose His Attire}

It is not within the scope of this article to attempt to explain why fashions in women's attire are in constant change. It need only be recognized that fashions are a historical fact and that women, no less than men, have always considered it a personal prerogative to change their manner of attire whenever they are so inclined. As there is a personal freedom to create fashions or to follow them, there is also a personal freedom not to follow them. For her own reasons, a woman may adopt a mode of dress that was fashionable centuries ago. For the most part, this is what women do when they enter upon the religious life. Their dress is modeled, with some exceptions, upon the attire of peasants and pilgrims of centuries ago. Perhaps the most distinctive characteristic about the attire of religious women is the wimple or headdress which was fashionable in the thirteenth century. In describing the headdress of this period, Mary Evans, in Costume throughout the Ages, says that "the cornette and shoulder length veil so fashionable about 1200 were followed soon afterwards by the coiffure en guimpe or wimple. This was a soft silk or linen veil so arranged that it enveloped the head and throat and formed an attractive frame for the face. A survival of this coiffure is seen today in the head covering of the nuns of various religious orders."31

In $O^{\prime}$ Connor v. Hendrick, ${ }^{32}$ a clear case of a public official attempting to enforce conformity in dress, the New York state superintendent of schools ordered a school district trustee to notify certain public school teachers "to forthwith discontinue the wearing in school of the distinctive dress or garb of

\footnotetext{
${ }^{30}$ Berghorn v. Reorganized School District, Circuit Court of Franklin County, Missouri, April 21, 1952.

${ }^{21}$ Evans, Costume throughout the Ages 36 (1930).

32109 App. Div. 361, 96 N.Y. Supp. 161 (4th Dep't, 1905).
} 
the religious order or sisterhood to which they belonged, and, if they refused to obey this requirement, that Hendrick [the trustee] . . . be enjoined from using any part of the school funds in payment of the wages of such teachers. ..."33 Refusal to conform because of religious belief brought with it the deprivation of wages specified by contract for services rendered to the state. Economic coercive measures were used to obstruct religious liberty in the face of state constitutional guarantees of religious freedom.

The question of personal religious liberty was sharply raised in 1895 when the State of Pennsylvania, inspired no doubt by the crusade of the American Protective Association, ${ }^{34}$ enacted legislation "to prevent the wearing in public schools of this commonwealth, by any teachers thereof, of any dress, insignia, marks or emblems indicating the fact that such teacher is an adherent or member of any religious order, sect or denomination. . . ."35 The constitutionality of the act was challenged under Article I, sections 3 and 4 of the Pennsylvania constitution. Section 3 provides that "all men have a natural and indefeasible right to worship Almighty God according to the dictates of their own conscience; ... no human authority can, in any case whatever, control or interfere with the rights of conscience. ..." Section 4 provides that "no person ... shall, on account of his religious sentiments, be disqualified to hold any office or place of trust or profit under this commonwealth."36

It would seem that the rights of religious women in their religious convictions were well secured by these guarantees. Nevertheless, the Supreme Court of Pennsylvania, in Commonvealth v. Herr, ${ }^{37}$ held valid the legislative discrimination against women wearing the religious dress. Inasmuch as the judiciary in a democratic government is constantly confronted with the problem of balancing personal rights and the demands of the common good, it is submitted that the following statement by the court had no relevance whatsoever to the issue before it. "It is impossible," said the court, "to see how civil government could exist, if the dictates of the individual conscience were

${ }^{33}$ Ibid., at 364, 163.

st This vindictive action on the part of the state legislature can probably best be explained by recalling that by the mid-90's the A.P.A. had succeeded in throwing most of the nation into a violent anti-Catholic hysteria. Congregational minister Washington Gladden, writing in 1894, quotes from a letter written by a physician in Pennsylvania's neighbor state Ohio as follows: "We have been, and still are, having an excitement in our usually quiet town, in regard to the Catholic question. There is not a Catholic in the entire township; but a large number of our people are intensely stirred up, some almost prostrated with fear, afraid that the Catholics are about making a wholesale attack upon Protestants, killing and plundering, and destroying our schools and churches. Of course it obtains the strongest foothold among the ignorant and unthinking, yet it seems to cause great uneasiness and fear among many of the more intelligent." Gladden, The Anti-Catholic Crusade, 47 Century Magazine 789 (1894). There is no reason to suspect that the antiCatholic sentiment was any less acute in Pennsylvania than in Ohio.

${ }^{35}$ Commonwealth v. Herr, $229 \mathrm{~Pa} .132,134,78$ Atl. 68, 69 (1910).

${ }^{36} \mathrm{Ibid}$, at $137,70$.

${ }^{37} 229 \mathrm{~Pa} .132,78$ Atl. 68 (1910). 
in every instance where they come in conflict with the law of the land the paramount rule of action."38 Such uncritical generalizations solve no cases. Neither does the converse of the generalization: "It is impossible to see how civil rights could exist, if the laws of the land were in every instance where they come in conflict with the individual conscience the paramount rule of action." The particular question before the court, in the instant case, was whether the impairment of the religious liberty of certain school teachers could be justified.

The right to the free exercise of religion is not an absolute right. But neither is the right of the legislature to enact laws restricting the religious liberty of the citizens. Any restrictions on religious liberty can be justified only to avoid or suppress the gravest evils and for the common good. The "evil" which the court sought to suppress in the instant case was the wearing of the religious dress in the public school classroom-a right that this very court had emphatically declared to be protected by the constitution of the state in the Hysong case. Yet this right could not now be exercised because, argued the court, the state has the right to "self-preservation." 39

The priority of the state's right to "self-preservation" demanded the suppression of the wimple in the public schools. However, the court made no effort to show how the wearing of the religious dress endangered the very existence of the state. It was the duty of the court to show that the clothes worn by these teachers was an evil of so great a magnitude that the state had a right to prohibit this particular exercise of religion. This it utterly failed to do. The rights of the individual, though inalienable and prior to those of the state, must be balanced against the rights of civil society. The balancing of these rights is, in great measure, the function of the courts, but they may not act arbitrarily; they must act reasonably-always keeping in view the rights of the individual and the demands of the common good.

The clear and present danger rule provides that the state must be in imminent danger of suffering a grave and pressing substantive evil resulting from a particular religious practice before it is justified in restricting that practice. ${ }^{40}$ The Supreme Court, speaking through Justice Rutledge, declared in Thomas v. Collins"1 that "the usual presumption supporting legislation is balanced by the preferred place given in our scheme to the great, the indispensable democratic freedoms secured by the First Amendment." ${ }^{\text {"2 }}$ Without

${ }^{28}$ Ibid., at 141, 71 .

${ }^{20}$ Ibid., at 143, 72.

${ }^{\circ}$ See Cantwell v. Connecticut, 310 U.S. 296 (1940); Thomas v. Collins, 323 U.S. 516 (1945); Barnette v. West Virginia Board of Education, 47 F. Supp. 251 (D. W.Va., 1942).

“ 323 U.S. 516 (1945).

2 Ibid., at 530. There is no unanimity among legal writers as to whether the Court has actually established a presumption of unconstitutionality. Mr. Antieau writes: "Although obviously the denial of a presumption of constitutionality does not automatically raise a presumption of unconstitutionality, the author considers such a presumption an effective 
wishing to hold the Pennsylvania Supreme Court of 1910 to present-day ideas of civil liberties, it must be observed, with respect, that the action of the court in denying religious liberty to the public school teachers was arbitrary and contrary to state constitutional provisions.

The Pennsylvania law of 1895 was not invoked to bar Masons from the state's educational institutions. It will be recalled that the purpose of the statute was "to prevent the wearing in the public schools . . . by any teachers ... of any dress, insignia, marks or emblems indicating the fact that such teacher is an adherent or member of any religious order, sect or denomination. ..."43 But members of Masonic Orders, like members of other religious groups, wear emblems and insignia that indicate their adherence to a particular religious belief. Masonry is a religion. ${ }^{44}$ The Masonic ring or lapel pin is, for the student in the public educational institution, as much a profession of faith in the Masonic religion as the religious dress is a profession of faith in the Catholic religion. Yet only teachers indicating their religious belief by their attire were barred from the state's schools.

When the plaintiff in Gerhardt $v$. Heid ${ }^{45}$ sought to restrain public school teachers from wearing a dress of religious significance, the Supreme Court of North Dakota declared that "the right of religious liberty is guaranteed and safeguarded by the Constitution. ..." The state constitution, section 4, provides that "the free exercise and enjoyment of religious profession and worship, without discrimination or preference shall be forever guaranteed in this state. . . ."46 The religious liberty guaranteed by the constitution cannot be denied to citizens teaching in the state's schools. "Each person engaged in teaching in our public schools," said the court, "is . . . guaranteed the same religious liberty that applies to every other person. . . ."47

Constitutional guarantees and judicial interpretations, however, do not always secure the religious freedom of individual members of minority groups.

weapon in the arsenal of those who would protect the constitutional freedoms." Antieau, The Task of Delimiting Fundamental Freedoms, 22 Temp. L. Q. 413, 421 (1949). But see Hamilton and Braden: "The current Bench, accentuating a trend which for a decade has been in the making, has in effect set up a presumption of unconstitutionality against all legislation which on its face strikes at freedom of speech, press, assembly, or religion." Hamilton and Braden, The Special Competence of the Supreme Court, 51 Yale L. J. 798 (1942).

${ }^{43}$ Commonwealth v. Herr, $229 \mathrm{~Pa} .132,134,78$ Atl. 68,69 (1910).

"Brother Albert G. Mackey, a celebrated Masonic authority, declared in his Encyclopaedia of Freemasonry, p. 639: "I contend, without any sort of hesitation, that Masonry is, in every sense of the word, except one, and that its least philosophical, an eminently religious institution. ..." Quoted in Preuss, A Study in American Freemasonry 95 (1920). (Italics Mackey's.) Arthur Preuss himself concludes in this extensive study that Freemasonry "is a religion." (Italics Preuss's.) Consult also Ward, Freemasonry, Its Aims and Ideals 183 et seq. (1923); Graebner, Is Masonry a Religion? 47 (1946).

${ }^{45} 66$ N.D. 444,267 N.W. 127 (1936).

${ }^{4} \mathrm{Ibid}$, at $449,130$.

${ }^{47}$ Ibid., at 458,135 . 
Though the North Dakota Supreme Court had held that, because of constitutional guarantees, public school teachers wearing the religious dress could not be barred from the classroom, the people of the state, by initiated measure, adopted an enactment which declared: "No teacher in any public school ... shall wear in said school . . . any dress or garb indicating the fact that such teacher is a member of or an adherent of any religious order, sect or denomination." 48 This violation of the religious liberty of public school teachers wearing the religious dress continues to be the law of the state.

In the case of Zellers v. Huff, ${ }^{40}$ the Supreme Court of New Mexico had before it a resolution adopted by the State Board of Education in 1951 declaring "that all nuns . . . wearing clothing of religious significance, should be removed from the public school. ... " ${ }^{\prime 50}$ Article II, section 11, of the state constitution provides that "every man shall be free to worship God according to the dictates of his own conscience," and Article XII, section 9, states that "no religious test shall ever be required as a condition of admission into the public schools or any educational institution of this state, either as a teacher or student. . . ."151 Notwithstanding these guarantees of religious liberty, and without offering a single argument based on constitutional principles, the Supreme Court of New Mexico upheld the resolution of the school board barring from the teaching profession those public school teachers who wore a certain attire because of their religious beliefs. ${ }^{52}$

In a case that is currently in litigation in Kentucky, involving efforts to oust public school teachers wearing the religious dress from schools in six counties, the Attorney General ruled that barring these women from the schools because of their religious dress would be a violation of their civil rights. The state constitution prohibits the teaching of sectarian doctrine. "So long," however, "as a Roman Catholic, Baptist, or Protestant teacher respects and observes these constitutional restraints," argued the Attorney General, "it is none of the business of the school board to question his or her religious faith or practices in their private life, or the clothes they wear privately or publicly, so long as those clothes are decent. . .."53 These public school teachers have a constitutional right under the guarantees of religious liberty to wear a particular fashion of dress because of their religious convictions. This right must be respected by the school board. Consequently, concluded the chief legal officer of the state, "for Kentucky school authorities to interfere with qualified Catholic sisters serving in our public schools because they wear the uniform of their religious order while teaching constitutes a persecution of the persons who are members of that order on account of their religion." ${ }^{254}$

\footnotetext{
${ }^{4}$ N.D. L. (1949) c. $356, \S 1$.

10 55 N.M. 501, 236 P. 2d 949 (1951).

${ }^{50}$ Ibid., at 516, $959 . \quad{ }^{5}$ Ibid., at 519, 960.

${ }^{83}$ Quoted in The St. Louis Register, June 11, 1954.

${ }^{52}$ Thid., at 531, 964.

"Ibid.
} 


\section{The Religious Dress: An Insignia of Belief, or a Didactic Device}

Inasmuch as the constitutions of virtually all the states prohibit the teaching of denominational religion in public schools, it is important to consider whether the wearing of the religious dress amounts to the teaching of a particular religious belief. To teach a particular religious belief means to impart knowledge of the doctrinal beliefs or truths that constitute the creed of the religion. The question to be considered is whether the wearing of the religious dress by a public school teacher teaches the beliefs of the one so attired, or merely indicates or manifests the particular religious adherence of the teacher.

The Supreme Court of Pennsylvania, considering religious dress as indicating or manifesting religious belief, declared: "Unquestionably, these women are Catholics, strict adherents of that faith, believing fully in its distinctive creed and doctrine. But this does not disqualify them. Our constitution negatives any assertion of incapacity or ineligibility to office because of religious belief." ${ }^{155}$ The court, penetrating to the basic issue involved in the case, stated that "if, by law, any man or woman can be excluded from public office or employment because he or she is a Catholic, that is a palpable violation of the spirit of the constitution; for there can be, in a democracy, no higher penalty imposed upon one holding to a particular religious belief than perpetual exclusion from public station because of it.".56

Pennsylvania law prohibits "sectarian" teaching in public schools. If the fashion of a teacher's dress reveals her religious adherence, is this sectarian teaching? The total history of the public school system of the state demonstrates that the wearing by the teacher of a distinctively religious garb is not sectarian teaching. "Ministers or preachers of many Protestant denominations wear a distinctively clerical garb," said the court. "No one has yet thought of excluding them as teachers from the school room on the ground that the peculiarity of their dress would teach to pupils the distinctive doctrines of the sect to which they belonged." ${ }^{257}$ There never was a time, said the court, when Protestant ministers wearing a distinctively clerical garb, were not frequently selected as teachers; in fact, the then state superintendent of public instruction was a Protestant preacher. In summarizing, the court said:

Ordination vows binding them to a particular creed were considered no disqualification. It was not assumed that the fact of membership in a particular church, or consecration to a religious life, or the wearing of a clerical coat or necktie, would turn the schools into sectarian institutions. ${ }^{.8}$

In the Hysong decision the Pennsylvania court stated a principle which has been accepted in other jurisdictions. It declared: "The [religious] dress is but the announcement of a fact, 一 that the wearer holds a particular religious

\footnotetext{
${ }^{5}$ Hysong v. School District of Gallitzin Borough, $164 \mathrm{~Pa} .629,655,30$ Atl. 482, 483 (1894).

${ }^{s}$ Ibid.

${ }^{67}$ Ibid., at 657, 484.

${ }^{\infty}$ Ibid.
} 
belief." the teacher.

The holding that the religious dress is but the announcement of a fact is based upon the assumption that only adherents of the Catholic belief wear the religious dress. This is not entirely in accord with the facts. The Encyclopedia Americana, in listing the principal religious orders of women in the United States, gives no less than twenty Protestant religious orders. The majority of these are engaged in teaching. Consequently, it cannot be unqualifiedly said that the religious dress is an announcement of the fact that the wearer holds a particular religious belief. There can be no certainty as to whether the school teacher attired in the religious dress is an Episcopalian or Catholic in belief.

The approach taken by the Pennsylvania Supreme Court is based upon an elemental fact in pedagogy, namely, that to teach a student that something is, is fundamentally different from teaching the student what something is. The former is mere knowledge of the existence of a thing; the latter is knowledge of the essence or nature of a thing. For example, it is one thing to know that an atomic bomb exists; it is something quite different to know the complete and intricate nature of the bomb. Similarly, it is one thing to know that a person is a Catholic; it is quite another thing to know the doctrinal truths and beliefs of that particular religious faith. Hence, it must be concluded that to indicate that one is a Catholic by an insignia or dress does not impart knowledge of a sectarian nature.

In the Gerhardt ${ }^{60}$ decision the Supreme Court of North Dakota followed the general principle enunciated by the Pennsylvania court. It declared that the religious dress, "it is true, proclaimed that the wearers were members of a certain denominational organization, but so would the wearing of the emblem of the Christian Endeavor Society or the Epworth League."161 To wear such emblems and thus to indicate their religious belief is their right, even as teachers. If a public school teacher wishes to indicate or manifest his or her religious belief by an emblem, pin, or ring, by the fashion of dress or suit, by the color of necktie worn, or by what he eats or does not eat in the school cafeteria, that is a personal religious matter-the exercise of which is protected by the state and the constitution. In an era that emphasizes the civil liberties of the individual person, the court could not accept a principle that would, if logically followed, necessitate the dismissal from public educational institutions and from public service of all Masons, all religious women, all members of the Christian Endeavor Society and of the Methodist Youth Fellowship, all ministers, all De Molays, and all others who indicate their religious adherence by an insignia of one kind or another.

so Ibid.

${ }^{\infty}$ Gerhardt v. Heid, 66 N.D. 444, 267 N.W. 127 (1936).

"Ibid., at 459, 135. 
The Supreme Court of Indiana, in Johnson v. Boyd, ${ }^{62}$ likewise rejected a religious test for the teaching profession. This decision was based on the state constitutional provisions, Article I, sections 3 and 5, that "no law shall, in any case whatever, control the free exercise and enjoyment of religious opinions, or interfere with the rights of conscience," and that "no religious test shall be required, as a qualification for any office of trust or profit." 63 On the basis of these constitutional guarantees, the court declared that no statute or rule prohibiting the employment of teachers belonging to a certain religious denomination or sect could be held valid. Moreover, "the employment of the teachers in this case certainly could not be held invalid because such teachers belonged to certain orders of the Catholic Church."64 Neither did the fact that these teachers "wore the robes of various orders to which they belonged constitute sectarian teaching or make it illegal for them to be paid their salaries as teachers." 65 "Are the courts to decide that the cut of a man's coat or the color of a woman's gown is sectarian teaching, because they indicate sectarian belief?"

The New York court assumed a contrary position in O'Connor v. Hendrick. ${ }^{67}$ This court, appealing to the constitutional prohibition against the use of public funds for teaching any denominational doctrine, ${ }^{68}$ intimated that the wearing of the religious dress in the classroom was "a part of a scheme for the teaching of the Catholic religion in this school." 69 To teach the Catholic religion is to impart information regarding the doctrines and the beliefs that constitute the cult and creed of Catholicism. The court did not show how this very difficult task is accomplished by the wearing of a particular fashion of clothes.

The Court of Appeals of New York, affirming the lower court, held that religious women are, by their distinctive dress, "necessarily and constantly asserting their membership in a particular church, and in a religious order within that church. . . ."70 Here, teachers are disqualified because their dress indicates membership in a particular religious belief; there was no question here of teaching denominational doctrines.

${ }^{62} 217$ Ind. 348,28 N.E. 2 d 256 (1940).

ॠ Ibid., at 370, 266.

at Ibid.

${ }^{65}$ Ibid. Article I, section 6, of the Constitution of Indiana provides that "no money shall be drawn from the treasury, for the benefit of any religious or theological institution." Section 4 of the same article provides that "no preference shall be given, by law, to any creed, religious society, or mode of worship...."The question of the religious garb arose in connection with the use by the public school system of inoperative parochial school facilities and the hiring of religious women to teach in these public schools.

${ }^{68}$ Johnson v. Boyd, 217 Ind. 348, 371, 28 N.E. 2d 256, 266 (1940).

${ }^{67} 109$ App. Div. 361, 96 N.Y. Supp. 161 (4th Dep't, 1905).

Ibid., at 367, 166.

${ }^{\infty}$ Ibid., at 369, 168.

${ }^{70}$ O'Connor v. Hendrick, 184 N.Y. 421, 429, 77 N.E. 612, 615 (1906). 
In Knovitton v. Baumhover ${ }^{71}$ the Supreme Court of Iowa also denied the right of women attired in the religious dress to teach in the state's schools. The Iowa court cites nothing but matters of administrative procedure and detail that are totally irrelevant to the basic constitutional question of whether or not these teachers taught a particular denominational religion in the public school by reason of their attire.

In the Kentucky religious garb case currently in litigation, the Attorney General reasoned that, while it is the purpose of the constitutional prohibition to outlaw sectarian indoctrination in the public schools, "you cannot acquire from these garbs any information as to the doctrines or ceremonial practices of the denomination to which the wearer belongs, and the wearing of these garbs does not constitute instruction in religious doctrine and practice."72

\section{Is a Virtuous LIFe Cause for Dismissal?}

During the nineteenth century, none of the very large number of Protestant clergyman teachers, though attired in the clerical garb, was dismissed from the public schools on the grounds that his practice of virtue inspired respect for the religion to which he belonged. Their dismissal would have violated the state's neutrality in religious matters and, what is of greater importance, it would have violated the religious freedom of these ministers. This fundamental freedom could not be denied because as an incidental byproduct of an individual's faith, he would inspire respect for his religion. Such impairment of religious freedom would have punished a person not for what he had done but for what he was. But today must a virtuous person hide or deny his religious identity, lest, like a criminal, he be deprived of the right to hold public office or teach in the state's schools? Such an attempt to drive religion back into the catacombs would make a farce of religious liberty.

To deprive a virtuous man of a public position lest his practice of virtue inspire respect for his particular religious belief is to impair his religious liberty. ${ }^{73}$ If, by hypothesis, all such persons were to be dismissed from the public schools, to whom would the education of our children be entrusted? Such exclusion would mean, in effect, that any public school teacher whose religious belief becomes known, whether by reason of dress, insignia, emblem, ring, diet, appearance, or by attending religious services, must be wary not to practice virtue lest he inspire respect for his particular belief. If his life

7182 Iowa 691, 166 N.W. 202 (1918).

${ }^{2}$ Quoted in The St. Louis Register, June 11, 1954.

${ }^{73}$ Secretary of Agriculture Benson is an Apostle of the Mormon Church and known to be such throughout the United States. This office is, in many respects, equivalent to that of Cardinal in the Catholic Church. Secretary Benson's virtuous qualities have certainly reflected favorably upon the Mormon religion. Is he for that reason to be ousted from office? U.S. Ambassador to Italy Clare Boothe Luce is known generally as a convert to Catholicism. Is her practice of virtue in the service of her country to be considered cause for dismissal because her way of life inspires respect for a particular religion? 
is evil, all is well; but if he should inspire respect, his influence would be considered sectarian and he would be subject to dismissal. The alternative is to conceal, hide, or deny his religious affiliations-but that is not the religious liberty guaranteed by the state and federal constitutions.

Applying the clear and present danger test to determine whether or not the evil that the state has a right to prevent is sufficiently grave to justify the impairment of religious liberty, it is clear that the "evil" which the courts and legislatures have sought to suppress is a "respect" for a particular religion. In order to suppress this "evil," religious freedom, one of the most important of our fundamental liberties that occupy a preferred position in the hierarchy of our constitutional values, is impaired. This respect which accrues to a religious belief because some public school teachers live their faith is, under this test, the "substantial evil" that is supposed to constitute a certain and imminent peril to the foundations of our society.

\section{RELIGIOUS GARB IN THE PUBLIC SCHOOLS A STUDY IN CONFLICTING LIBERTIES}

American society is protected on both a national and state level by constitutional guarantees of freedom of religion. ${ }^{1}$ Such guarantees imply that religious freedom

must be so exercised by him to whom it is given as not to infringe upon the equally sacred right of his neighbor to differ with him. ${ }^{2}$

\section{Application of this principle dictates that the states must}

maintain the common school system free from sectarian influence or control and ... preserve the equal right of every citizen to have his children educated in these schools of the people without being subjected to the slightest sectarian leading upon the part of their teachers. ${ }^{3}$

\footnotetext{
${ }^{1}$ Two federal constitutional provisions apply to religious liberty. "[N]o religious test shall ever be required as a qualification to any office or public trust under the United States." U.S. Const. Art. 6, $\$ 3$. "Congress shall make no law respecting an establishment of religion, or prohibiting the free exercise thereof. . . ." U.S. Const. Amend. 1. The latter principle has also been held applicable to state action by the Fourteenth Amendment. Everson v. Board of Education, 330 U.S. 1 (1947); Zellers v. Huff, 55 N.M. 501, 236 P. 2d 949 (1951). The state constitutions generally follow the federal constitutional provisions in this area.

"All states provide religious liberty to a greater or less degree. Most states prohibit the use of religious tests as qualifications for holding public office, altho in several, atheists are excluded. Compulsory attendance at places of public worship is universally unconstitutional. ... [J] udicial interpretation has usually gone to the spirit of the language and the courts are unanimous in holding that no union of church and state is possible under our state constitutions." 24 Research Bulletin of the National Education Association 13 (1946).

${ }^{2}$ Knowlton v. Baumhover, 182 Iowa 691, 703, 166 N.W. 202, 206 (1918).

${ }^{8}$ Ibid., at $719,211$.
} 